ISSN 0258-7122 (Print), 2408-8293 (Online)

Bangladesh J. Agril. Res. 44(4): 577-590, December 2019

\title{
INFLUENCE OF PLANT GROWTH REGULATORS ON VEGETATIVE GROWTH, SEX EXPRESSION AND YIELD OF SUMMER BOTTLE GOURD
}

\author{
M. MONIRUZZAMAN ${ }^{1}$, R. KHATOON ${ }^{2}$, M. MONIRUZZAMAN ${ }^{3}$ \\ AND A. K. M. QAMRUZZAMAN ${ }^{4}$
}

\begin{abstract}
Field experiments on bottle gourd variety 'BARI Lau -4' were conducted at the Plant Physiology field of Horticulture Research Center, Bangladesh Agricultural Research Institute, Gazipur during two consecutive summer seasons of 2015 and 2016 to investigate the effect of plant growth regulators on growth, sex expression, yield and yield components of the crop. The experiment consisted of different concentrations of Gibberellic acid $\left(\mathrm{GA}_{3}\right)$, Naphthalene acetic acid (NAA), Maleic hydrazide $(\mathrm{MH})$ and single concentration of cycocel (CCC) viz., GA 3 @10 ppm, GA 3 @30 ppm, NAA@100 ppm, NAA@150 ppm, MH@50 ppm, MH @ 150 ppm and CCC @ 500 ppm along with distilled water considered as control. All growth regulators were sprayed to the seedlings at two-leaf stage and 4 days after the first spray. Growth regulator treatments had significant effect on primary branches/plant, node number of $1^{\text {st }}$ male and female flower appearance, number of days to $1^{\text {st }}$ male and female flower appearance, number of male and female flowers, sex ratio (male:female flower) number of fruits/plant, individual fruit weight and fruit yield. Spraying of MH @ 150 ppm gave the highest primary branches/plant (17.0 and 18.0 in first and $2^{\text {nd }}$ year, respectively) and induced maximum female flowers (37.3 and 40.0 in first and $2^{\text {nd }}$ year, respectively) at lower nodes followed by CCC @ 500 ppm (36.3) in the first year and $\mathrm{MH} @ 50 \mathrm{ppm}$ (40.0) in the $2^{\text {nd }}$ year. Application of MH @ 150 ppm caused early appearance of female flowers on the nearest node (from bottom). Application of MH @ 150 ppm gave the lower number of male flowers (81.7 and 96.0 in first and $2^{\text {nd }}$ year, respectively) and the highest number of female flowers/plant, thereby producing lower male:female sex ratio (2.2 and 2.5 in first and $2^{\text {nd }}$ year, respectively) and the maximum number of fruits/plant (12.0 and 14.0 in first and $2^{\text {nd }}$ year, respectively). The maximum fruit weight/plant was obtained from the application of $\mathrm{MH} @ 150$ ppm (29.3 and 35.8 in first and $2^{\text {nd }}$ year, respectively) followed by CCC @ 500 ppm (26.0 in the $1^{\text {st }}$ year and 29.0 in $2^{\text {nd }}$ year). The highest fruit yield per hectare was recorded significantly with the application of MH @ 150 ppm (97.6 t/ha and $89.6 \mathrm{t} / \mathrm{ha}$ in first and $2^{\text {nd }}$ year, respectively) closely followed by CCC @ 500 ppm (88.5 t/ha in 2015) and $\mathrm{GA}_{3} @ 30$ ppm (75.3 t/ha in 2016), as compared to
\end{abstract}

${ }^{1}$ Principal Scientific Officer, Plant Physiology Section, Horticulture Research Centre (HRC), Bangladesh Agricultural Research Institute (BARI), Gazipur, ${ }^{2 \& 3}$ Scientific Officer, Plant Physiology Section, Horticulture Research Centre (HRC), BARI, Gazipur, ${ }^{4}$ Principal Scientific Officer, Olericulture Division, Horticulture Research Centre (HRC), BARI, Gazipur, Bangladesh. 
other treatments. The highest mean yield over the years was also recorded at MH@ 150 ppm (93.6 t/ha) followed by CCC @ 150 ppm (80.6 t/ha) and GA 3 30 (74.1). Application of MH @ 150 ppm gave the maximum gross return and net return with the highest BCR of 5.24 followed by CCC 500 ppm (4.15) and $\mathrm{GA}_{3} 30$ ppm (3.86).

Keywords: Growth regulators, sex expression, fruit yield, summer bottle gourd.

\section{Introduction}

Bottle gourd [Lagenaria siceraria (Molina) Standle] locally known as 'Lau' or 'Kadu', is one of the important and popular vegetables of the family Cucurbitaceae, extensively grown throughout Bangladesh. Fruits at tender stage are used as a cooked vegetable and for preparation of sweets (e.g. kheer, petha, burfi and halwa), pickles and rayta. Hard shells of mature fruits are used as water jugs, domestic utensils, floats for fishing nets and making musical instruments, etc. As a vegetable it is easily digestible. It has cooling effect and has diuretic and having cardio-tonic properties. Fruit pulp is used as an antidote against certain poisons and is good for controlling constipation, night blindness and cough. It is especially recommended in the diet of patients suffering from high blood pressure. The composition of immature fruits of bottle gourd per $100 \mathrm{~g}$ of fresh edible portion consists of water $93.9 \mathrm{~g}$, energy $88 \mathrm{~kJ}(21 \mathrm{kcal})$, protein $0.5 \mathrm{~g}$, fat $0.1 \mathrm{~g}$, carbohydrate $5.2 \mathrm{~g}$, fiber $0.6 \mathrm{~g}$, Ca $44 \mathrm{mg}, \mathrm{P} 34 \mathrm{mg}$, Fe $2.4 \mathrm{mg}, \beta$-carotene $25 \mu \mathrm{g}$, thiamin $0.03 \mathrm{mg}$, niacin $1.2 \mathrm{mg}$, ascorbic acid $10 \mathrm{mg}$ (Leghari et al., 2014).

The growth and yield of cultivated crop plants is mainly influenced by genetic and crop management factors; first factor involves in various breeding techniques while second factor involves cultural operation, plant protection and other agronomic practices, both these factors have been fully exploited by researchers. In recent years, scientists have given attention to the idea of regulating plant growth as third most important factor in improving growth and yield. It helps in efficient utilization of metabolites in certain physiological processes going in plant system (Krisnamurthy, 2011).

Bangladesh Agricultural Research Institute (BARI) has developed five bottle gourd varieties for cultivation in both winter and summer seasons. The variety 'BARI Lau-4' is recommended for cultivation in both winter and summer season. In summer season, the yield of bottle gourd is low. Besides many other reasons for low yield of bottle gourd, there is one acute problem of fewer female flowers and high sex ratio (male:female) during summer. In cucurbitaceous plants, sex expression is determined by gene as well as the environment. Huyskens et al. (1992) reported that significantly more male flowers were produced during summer, under long days and high temperature, than in winter, under short days and low temperature condition. Plant growth regulators (PGRs) such as Gibberellic acid $\left(\mathrm{GA}_{3}\right)$, Naphthalene acetic acid (NAA), Maleic hydrazide $(\mathrm{MH})$, Cycocel (CCC), etc. are found beneficial for induction of female flowers and reduction of male flowers in summer bottle gourd and sex expression can also be 
controlled by using different growth regulators (Kooner et al., 2000; Rahman and Karim, 1997; Hidayatullah et al., 2012; Gaurav et al., 2008 and Kumar et al., 2000). Very little information is available on the effect of growth regulators on sex expression and yield of bottle gourd in Bangladesh. Therefore, this investigation was carried out to assess the effect of PGRs $\left(\mathrm{GA}_{3}, \mathrm{NAA}, \mathrm{MH}\right.$ and CCC) on vegetative growth and to narrow the sex ratio by increasing female flowers side by side, decreasing male flowers per plant for yield improvement of bottle gourd in summer.

\section{Materials and Methods}

The experiment was conducted at the Plant Physiology field of HRC, BARI, Gazipur during two consecutive summer seasons of 2015 and 2016.The variety 'BARI Lau-4' was used in this experiment. The experiment consisted of eight treatments viz., $\mathrm{T}_{0}=$ control (distilled water), $\mathrm{T}_{1}=\mathrm{GA}_{3} @ 10 \mathrm{ppm}, \mathrm{T}_{2}=\mathrm{GA}_{3} @$ 30 ppm, $\mathrm{T}_{3}=\mathrm{NAA} @ 100$ ppm, T $4=\mathrm{NAA} @ 150$ ppm, T $5=\mathrm{MH} @ 50$ ppm, $\mathrm{T}_{6}=\mathrm{MH} @ 150 \mathrm{ppm}$ and $\mathrm{T}_{7}=\mathrm{CCC} @ 500$ ppm. The sources of $\mathrm{GA}_{3}$ and CCC were Isha, Chemical Pvt. Ltd. (India), and those of MH and NAA were BDH Chemicals Ltd. (England) and SD Fine Chemicals Ltd. (Mumbai, India), respectively. All chemicals were Laboratory Grade.

$250 \mathrm{mg}$ of gibberellic acid was accurately weighed out using sensitive electronic balance and dissolved in a few $\mathrm{ml}$ of alcohol $(95 \%)$. The solution thus prepared was transferred to $250 \mathrm{ml}$ volumetric flask containing distilled water. The volume of the solution was made upto $250 \mathrm{ml}$ to get the $1000 \mathrm{ppm}$ stock solution. NAA stock solution (1000 ppm) was prepared by dissolving $500 \mathrm{mg}$ NAA powder in $500 \mathrm{ml}$ of distilled water. $500 \mathrm{mg}$ NAA powder was accurately weighed out and dissolved by keeping it in a $500 \mathrm{ml}$ volumetric flask and by adding $1 \mathrm{~N} \mathrm{NaOH}$ solution drop by drop till the powder was completely dissolved. The volume was adjusted to $500 \mathrm{ml}$ with distilled water in a volumetric flask. Thus the stock solution was prepared. $500 \mathrm{mg} \mathrm{MH}$ was accurately weighed out using sensitive electronic balance and dissolved in a few $\mathrm{ml}$ of $1 \mathrm{~N} \mathrm{NaOH} .100 \mathrm{ml}$ of distilled water was added in a $500 \mathrm{ml}$ volumetric flask. The solution was then adjusted to $500 \mathrm{ml}$ by adding distilled water. This gives 1000 ppm stock solution. $2 \mathrm{ml} \mathrm{(50 \%}$ ai) of CCC was taken by $10 \mathrm{ml}$ pipette ans dissolved in distilled water by addingshaking method. The volume was adjusted to $1000 \mathrm{ml}$ with distilled water in a volumetric flask to obtain a stock solution of $1000 \mathrm{ppm}$. Finally, the required lower concentrations of GA3 (10 and $30 \mathrm{ppm})$, NAA (100 and $150 \mathrm{ppm}), \mathrm{MH}$ $(50$ and $150 \mathrm{ppm})$ and $\mathrm{CCC}(500 \mathrm{ppm})$ were prepared from their stock solutions by using the formula: $V_{1} \times S_{1}=V_{2} \times S_{2}$; where. $S_{1}$ : concentration of stock solution $(1000 \mathrm{ppm})$ of the desired chemical $\left(\mathrm{GA}_{3}, \mathrm{NAA}, \mathrm{MH}\right.$ or $\left.\mathrm{CCC}\right), \mathrm{V}_{1}=$ volume of stock solution of desired chemical (what we have to calculate), $\mathrm{S}_{2}$ : concentration of desired chemical and $\mathrm{V}_{2}$ : amount of solution required for spray treatment-wise. Then calculated amount $\left(\mathrm{V}_{1}\right)$ of desired chemical was taken from stock solution and poured into a pot of known volume and then required amount 
of water was added into this pot. Hand sprayer was used for spray of the chemicals.

The experiment was laid out in a randomized complete block design (RCBD) with three replications. For raising seedlings sandy loam soil and well decomposed cowdung were thoroughly mixed in 1:1 ratio and then plastic pots were filled with this mixture. Seeds were placed in plastic pots on 01 March, 2015 and 11 February, 2016. Seeds were soaked in distilled water for 24 hours to facilitate germination. After final land preparation, pits were prepared by spade and size of each pit was $30 \mathrm{~cm} \times 30 \mathrm{~cm}$ x $30 \mathrm{~cm}$. One pit was made in the middle of each plot and one seedling was planted in that pit. Plot size was $2.0 \mathrm{~m} \times 1.5$ $\mathrm{m}$ and $2.0 \mathrm{~m} \times 2.0 \mathrm{~m}$ in 2015 and 2016, respectively. Manure and fertilizers were applied as cow dung, N, P, K, S, B and Zn @ 10000, 80, 45, 88, 25, 1.8 and 4.5 $\mathrm{kg} / \mathrm{ha}$, respectively (Quamruzzaman et al., 2015). Half of cow dung; full doses of $\mathrm{S}, \mathrm{Zn}$ and $\mathrm{B}$, and $\mathrm{P}$ and $\mathrm{K} @ 30 \mathrm{~kg} / \mathrm{ha}$ each were applied during final land preparation. The rest half of cow dung and P and K @ $15 \mathrm{~kg} / \mathrm{ha}$ was applied as basal in pit. Rest of $\mathrm{N}$ and $\mathrm{K}$ was applied in 4 equal installments at 20 days interval starting from 20 days after transplanting. Seventeen day- old seedlings were transplanted on 19 March 2015 and 01 March 2016. First spraying of plant growth regulators (PGRs) were done at the 2 true leaf stage on March 23, 2015 and 03 March, 2016. Second spraying of PGRs was done after 4 days of first spray. Control plants were sprayed with distilled water. Trellises made of bamboos and iron nets were used for the support of each plant individually. Plants were allowed to be grown individually and not be allowed to intermingle with other plants grown beside. Weeding and irrigation were done as required. When $1^{\text {st }}$ flower was seen, it was tagged and each male and female flower was tagged separately throughout the growing period, and the number of male and female flowers was counted.

Data were recorded on main vine length, number of primary branches/plant, number of leaves/plant, CCI (Chlorophyll Content Index), Fv/Fm (efficiency of photosystem II), days to first male and female flowers, node order of first and female flowers (from the bottom), number of male and female flowers/plant, number of fruits/plant, individual fruit weight, fruit length, fruit circumference and yield/plot. Then plot yield was converted to per hectare yield. Data on CCI (Chlorophyll Content Index) was taken by Chlorophyll Content Meter (Model: CCM-200, Opti-sciences, USA). The leaf discs were previously adapted to the dark for 20 minutes. The fluorescence data $(\mathrm{Fv} / \mathrm{Fm})$ were collected at 70 days after sowing within $10.00 \mathrm{am}$ to $12.00 \mathrm{pm}$. In the first year (2015), the fruit harvest started from 21 May and ended in 18 June; while, in the $2^{\text {nd }}$ year (2016), fruit harvest started from 09 May and ended in 29 June. Each fruit was harvested after twelve days of anthesis. Thus every fruit was harvested by sharp knife 12 days after anthesis. A total of 7 and 8 harvests were required in 2015 and 2016, respectively. Recorded data were statistically analyzed by MSTAT-C and mean separation was done by Tukey's W test at 5\% level of probability. 


\section{Results and Discussion}

\section{Vegetative growth of bottle gourd plants}

Plant growth regulators had significant effect on number of primary branches/plant in both the years. The number of leaves/plant was significantly influenced by growth regulators in 2015 but insignificant effect on length of main vine in both years (Table 1). The maximum number of primary branches/plant was recorded in the plants treated with MH @ 150 ppm (17.0 and 18.0 in 2015 and 2016, respectively; mean 17.5) closely followed by CCC @ 500 ppm (15.0 in both 2015 and 2016; mean 15.0) and MH @ 50 ppm (13.0 in 2015 and 15.0 in 2016, mean 14.00) and $\mathrm{GA}_{3} @ 30$ ppm (12.0 in 2015 and 16.0 in 2016, mean 14.0) and its minimum number from control in both years (6.0 in 2015 and 8.0 in 2016; mean 7.0). Ansari and Choudhury (2014) obtained significantly higher number of branches in bottle gourd by the application of $\mathrm{GA}_{3}(50-100 \mathrm{ppm})$ and MH @ 50 ppm. Sadiq et al. (1990) reported to have the highest number of branches per plant in cucumber while spraying with CCC @ 500 ppm at 4 leaf stage. In the first year, spraying of MH @ 150 ppm gave the maximum number of leaves/plant (343.0) which was identical with MH @ 50 ppm (337.0) and CCC @ 500 ppm (341.0). Number of leaves/plant did not vary significantly with PGR treatments in the $2^{\text {nd }}$ year, but numerically the PGR treated plants produced more leaves than control. The highest mean number of leaves/plant (325.0) was recorded at both MH@150 ppm and CCC @ 500 ppm. The control treatment gave the minimum number of leaves/plant in both the years.

Table 1. Effect of plant growth regulators on vegetative growth of summer bottle gourd

\begin{tabular}{c|c|c|c|c|c|c|c|c|c}
\hline \multirow{2}{*}{ Treatment } & \multicolumn{3}{|c|}{$\begin{array}{c}\text { Main vine length } \\
(\mathrm{m})\end{array}$} & \multicolumn{3}{c|}{$\begin{array}{c}\text { Primary branches/plant } \\
\text { (no.) }\end{array}$} & \multicolumn{3}{c}{ Leaves/plant (no.) } \\
\cline { 2 - 11 } & 2015 & 2016 & Mean & 2015 & 2016 & Mean & 2015 & 2016 & Mean \\
\hline $\mathrm{T}_{0}$ & 12.2 & 12.0 & 12.1 & $6.0 \mathrm{e}$ & $8.0 \mathrm{c}$ & 7.0 & $277 \mathrm{~d}$ & 298 & 288. \\
$\mathrm{~T}_{1}$ & 12.2 & 12.1 & 12.1 & $11.0 \mathrm{~cd}$ & $10.0 \mathrm{c}$ & 10.5 & $304 \mathrm{~cd}$ & 310 & 307 \\
$\mathrm{~T}_{2}$ & 12.1 & 13.2 & 12.6 & $12.0 \mathrm{bcd}$ & $16.0 \mathrm{a}$ & 14.0 & $309 \mathrm{bcd}$ & 318 & 314 \\
$\mathrm{~T}_{3}$ & 12.3 & 12.4 & 12.4 & $9.0 \mathrm{de}$ & $11.0 \mathrm{bc}$ & 10.0 & $285 \mathrm{~d}$ & 300 & 294 \\
$\mathrm{~T}_{4}$ & 11.9 & 13.2 & 12.6 & $9.0 \mathrm{de}$ & $10.0 \mathrm{c}$ & 9.5 & $298 \mathrm{~d}$ & 308 & 303 \\
$\mathrm{~T}_{5}$ & 12.4 & 12.6 & 12.5 & $13.0 \mathrm{abc}$ & $15.0 \mathrm{ab}$ & 14.0 & $337 \mathrm{abc}$ & 309 & 323 \\
$\mathrm{~T}_{6}$ & 13.0 & 11.8 & 12.4 & $17.0 \mathrm{a}$ & $18.0 \mathrm{a}$ & 17.5 & $343 \mathrm{a}$ & 307 & 325 \\
$\mathrm{~T}_{7}$ & 13.00 & 11.8 & 12.4 & $15.0 \mathrm{ab}$ & $15.0 \mathrm{ab}$ & 15.0 & $341 \mathrm{ab}$ & 309 & 325 \\
\hline $\mathrm{CV}(\%)$ & 3.94 & 10.37 & - & 10.97 & 10.73 & - & 3.62 & 5.31 & - \\
\hline
\end{tabular}

Means showing dissimilar letters in a column are significantly different at $5 \%$ level by Tukey's W test.

$\mathrm{T}_{0}=$ Control (distilled water), $\mathrm{T}_{1}=\mathrm{GA}_{3} @ 10 \mathrm{ppm}, \mathrm{T}_{2}=\mathrm{GA}_{3} @ 30 \mathrm{ppm}, \mathrm{T}_{3}=\mathrm{NAA} @$ 100 ppm, $\mathrm{T}_{4}=\mathrm{NAA} @ 150 \mathrm{ppm}, \mathrm{T}_{5}=\mathrm{MH} @ 50 \mathrm{ppm}, \mathrm{T}_{6}=\mathrm{MH} @ 150 \mathrm{ppm}, \mathrm{T}_{7}=\mathrm{CCC}$ @ $500 \mathrm{ppm}$. 


\section{Effect of PGRs on CCI and Fv/Fm values}

In both the years all growth regulator treated plants produced identical chlorophyll content index (CCI) and $\mathrm{Fv} / \mathrm{Fm}$ with control (Table 2). All the treatments gave $\mathrm{Fv} / \mathrm{Fm}$ values close to 0.80 indicating photosystem II of the plants were not affected by the application of PGRs. The Fv/Fm values close to 0.800 revealed that all the plants under treatment were in healthier condition.

Table 2. Effect of plant growth regulators on chlorophyll content and quantum yield (Fv/fm values) of summer bottle at 70 days after sowing

\begin{tabular}{c|c|c|c|c|c|c}
\hline \multirow{2}{*}{ Treatment } & \multicolumn{3}{|c|}{ CCI value } & \multicolumn{3}{c}{ Fv/Fm value } \\
\cline { 2 - 7 } & 2015 & 2016 & Mean & 2015 & 2016 & Mean \\
\hline $\mathrm{T}_{0}$ & 20.2 & 21.3 & 20.7 & 0.80 & 0.81 & 0.81 \\
$\mathrm{~T}_{1}$ & 20.3 & 21.5 & 20.9 & 0.80 & 0.81 & 0.81 \\
$\mathrm{~T}_{2}$ & 21.4 & 22.3 & 21.9 & 0.80 & 0.82 & 0.81 \\
$\mathrm{~T}_{3}$ & 20.5 & 20.2 & 20.4 & 0.81 & 0.81 & 0.81 \\
$\mathrm{~T}_{4}$ & 20.6 & 21.2 & 20.9 & 0.81 & 0.81 & 0.81 \\
$\mathrm{~T}_{5}$ & 20.7 & 20.1 & 20.4 & 0.80 & 0.80 & 0.80 \\
$\mathrm{~T}_{6}$ & 20.7 & 20.8 & 20.8 & 0.80 & 0.82 & 0.80 \\
$\mathrm{~T}_{7}$ & 20.4 & 21.3 & 20.9 & 0.80 & 0.80 & 0.80 \\
\hline $\mathrm{CV}(\%)$ & 5.20 & 4.88 & 5.13 & 3.08 & 4.60 & 3.52 \\
\hline
\end{tabular}

$\mathrm{T}_{0}=$ Control (distilled water), $\mathrm{T}_{1}=\mathrm{GA}_{3} @ 10 \mathrm{ppm}, \mathrm{T}_{2}=\mathrm{GA}_{3} @ 30 \mathrm{ppm}, \mathrm{T}_{3}=\mathrm{NAA} @$ 100 ppm, $\mathrm{T}_{4}=\mathrm{NAA} @ 150$ ppm, $\mathrm{T}_{5}=\mathrm{MH} @ 50$ ppm, $\mathrm{T}_{6}=\mathrm{MH} @ 150$ ppm, $\mathrm{T}_{7}=\mathrm{CCC}$ @ $500 \mathrm{ppm}$.

\section{Node number and number of days to first male and female flowers}

Number of node and days required for the appearance of the first male flower were significantly lowered by all PGRs treatments except control (Table 3). The first male flower appeared at the lowest node (18.0 in 2015 and 16.3 in 2016; mean 17.15) on the plants treated with MH @ 150 ppm. The node numbers required for the first male flower were identical in NAA @ 100 ppm, NAA @150 ppm, MH @ 50 ppm, MH @ 150 ppm and CCC @ 500 ppm in the $1^{\text {st }}$ year whereas, in $2^{\text {nd }}$ year, node numbers were identical in all treatments except control. The plants treated with $\mathrm{MH} @ 150 \mathrm{ppm}$ produced the first male flower in the least number of days in both years $(59.0$ in 2015, 63.0 in 2016 with a mean value 61.0. MH @ 150 ppm was statistically similar to $\mathrm{GA}_{3} @ 30$ ppm, and CCC @ 500 ppm with regard to number of days to first male flower appearance in $2^{\text {nd }}$ year. All the PGR treatments significantly lowered the number of nodes and days required for the appearance of the first female flower than control in 2015 but, in 2016, application of MH both at 50 and $150 \mathrm{ppm}$ significantly reduced node number at which female flower appeared and all the PGR treatments significantly lowered number of days required for the appearance of first female flower as compared to control (Table 3). The first 
female flower appeared at the lowest node (21.0 in 2015 and 20.0 in 2016; mean $20.5)$ in the plants treated with MH @ 150 ppm, closely followed by CCC @ 500 ppm, MH @ 50 ppm and NAA @ 150 ppm during 2015, but in 2016, there was no significant differences among PGR treatments in respect of node number of female flower except control. Heslop-Harrison (1957) reported that the sexual differentiation is controlled by endogenous level of auxin content, which favours the formation of female flowers. Browning et al. (1992) explained that paclobutrazol induced a large, but transient increase in IAA (natural auxin) concentration within two days after treatment of the plants. These seem to be a reasonable explanation for the early appearance of female flowers at lower node. Similar findings have been reported with CCC by Sharma et al. (1988) and with MH by Singh and Choudhury (1988), Patel (1992) and Pandya and Dixit (1997) in bottle gourd. The plants treated with MH @ 150 ppm were able to produce the first female flower in least number of days in both the years (70.0 in 2015, 74.3 in 2016 and mean value 72.15. $\mathrm{MH}$ at $50 \& 150 \mathrm{ppm}$ and $\mathrm{GA}_{3} @ 30 \mathrm{ppm}$ gave identical number of days to $1^{\text {st }}$ female flower in 2015 whereas, in 2016, MH @ 150 ppm was statistically similar to $\mathrm{GA}_{3} @ 30$ ppm with regard to number of days to first female flower appearance.

\section{Male and female flowers}

Spraying of CCC @ 500 ppm gave the highest number of male flowers (143.3 in 2015) followed by control treatment (123.0 in 2015) but in 2016, this treatment produced lower male flower than control (Table 3). The lowest male flowers/plant (81.7 in 2015, 96.0 in 2016 and mean 88.8) was recorded at MH @ 150 ppm, which was identical with NAA @ 100 and MH @ 50 ppm in 2015; but in 2016, it was identical with NAA @ 100 and 150 @ ppm. In 2015, all treatments significantly produced the maximum female flowers/plant while in 2016, except NAA @ 150 ppm all other treatments significantly increased number of female flowers/plant as compared to control. In the first year, the maximum number of female flowers/plant was found in $\mathrm{MH} @ 150$ ppm (37.3 in 2016, 40 in 2016; mean 38.7) closely followed by CCC @ 500 ppm (36.3 in 2015, 38.0 in 2016; mean 38.0) and GA $@ 30$ ppm (34.0 in 2016).

The CCC has been reported to cause reduction in respiration rate and accumulation of photosynthates, an effect similar to low temperature and short days (Choudhury, 1996) which might promote female flower production in cucurbits. Desai et al. (2011) obtained male flowers ranging from 86.27 -151 (CCC @ $250 \mathrm{ppm}$ ); 111.43 by control treatment and female flowers with a range of 29.7 (control) to 51.1 (PBZ @ 25 ppm); 40.5 by CCC. The present experimental result corroborates the rfindings of Hidayatullah et al. (2012). Pandey and Singh (1976) reported that spraying of NAA @ 100 and $150 @$ ppm and $\mathrm{GA}_{3} @ 10$ ppm increased the female flowers and decreased the male flowers per plant in sponge gourd compared to control. The present experimental results were also in agreement with the results of Pandey and Singh (1976) and Arora et al. (1982). 

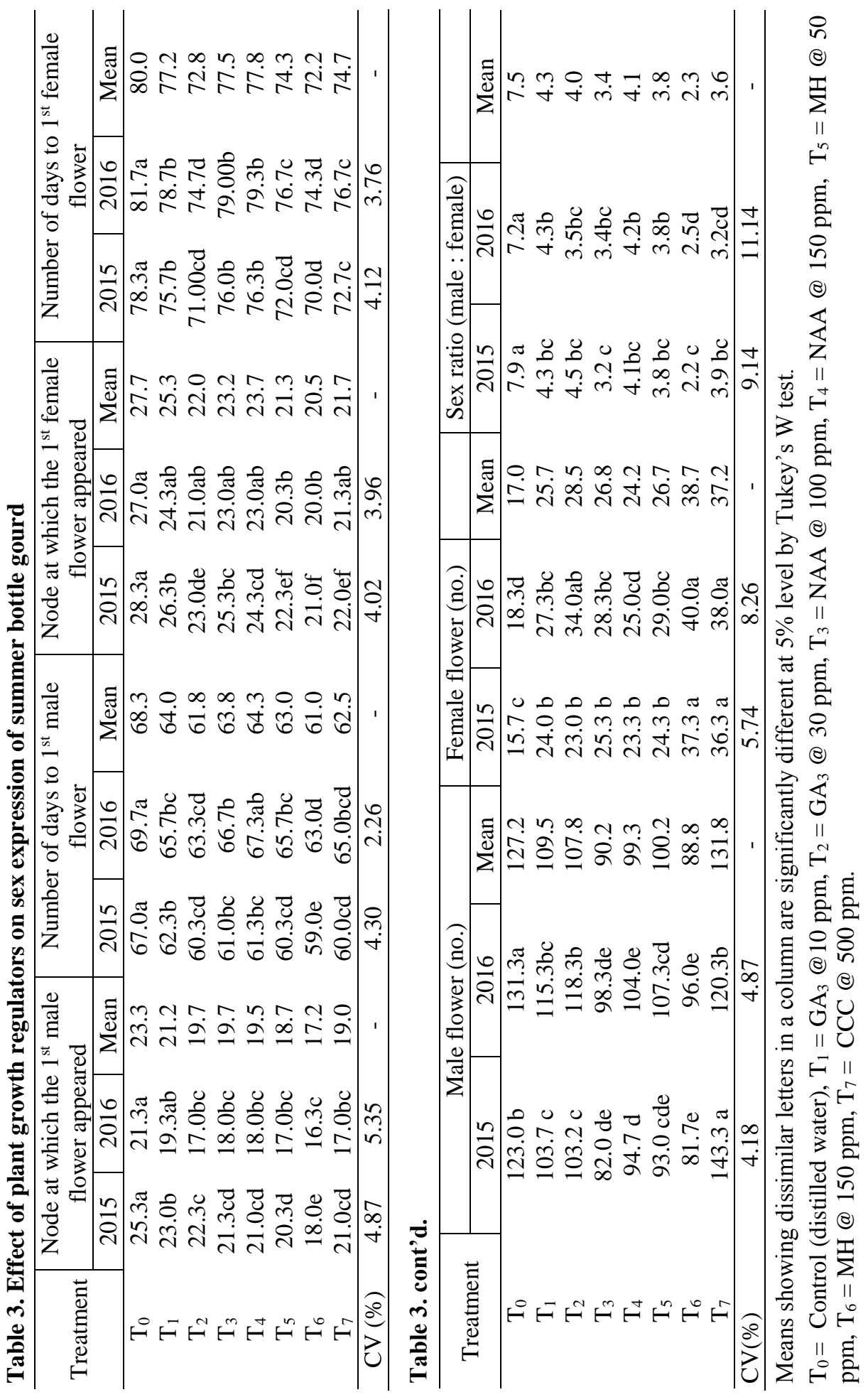







\section{Sex ratio of male and female flower}

All the treatments resulted in narrowing down of male-female sex ratio over control in both years (Table 3).The lowest sex ratio (male:female) was recorded at MH @ 150 ppm in both the years (2.2 in 2015 and 2.5 in 2016; mean 2.30 ). In 2015, all the treatments except control produced identical values of sex ratio, but in 2016, MH @ 150 and CCC @ 500 were identical with regard to sex ratio. Again, in 2016, there was no significant difference among GA $\mathrm{G}_{3} @ 10\left(\mathrm{~T}_{1}\right), \mathrm{GA}_{3} @$ $30\left(\mathrm{~T}_{2}\right)$, NAA @ $100\left(\mathrm{~T}_{3}\right)$, NAA @ $150\left(\mathrm{~T}_{4}\right)$ and $\mathrm{MH} @ 150\left(\mathrm{~T}_{5}\right)$ ppm in respect of sex ratio. Although CCC @ 500 ppm produced the maximum male flowers compared to control in 2015, it gave lower sex ratio (3.9) than control (7.9) because of producing higher female flowers.

The marked suppression of male flowers and induction of female flowers by all concentrations of $\mathrm{GA}_{3}$, NAA, MH and CCC @ 500 ppm was noticed. Induction of female flowers by all concentrations of PGRs was the evidence of lowered sex ratio. The sex ratio recorded in this investigation was comparable to the results reported by Hidayatullah et al. (2012) with $\mathrm{GA}_{3}$, Sharma et al. (1988) as well as Pandya and Dixit (1997) with CCC and Ingle et al. (2000) as well as Arora et al. (1982) with MH in bottle gourd.

\section{Yield attributes and yield of bottle gourd}

Growth regulator treatments had significant effect on yield components and yield of bottle gourd except fruit length, fruit circumference and individual fruit weigh in both the years (Table 4). The maximum number of fruits/plant was found in MH@ 150 ppm in both the years (12.0 in 2015 and 14.0 in 2016; mean 13.0). In the first year, MH @ 150 ppm gave identical fruit number with CCC @ 500 ppm (11.3), but in the $2^{\text {nd }}$ year, number of fruits produced by the plants treated with MH 150 ppm was statistically similar to those of $\mathrm{GA}_{3} @ 30 \mathrm{ppm}$ (12.0). The lowest number of fruits was obtained from control in both the years $(4.7$ in 2015 and 6.7 in 2016; mean 5.7). The maximum fruit weight/plant was recorded at MH @ 150 ppm in both the years $(29.3 \mathrm{~kg}$ and $35.8 \mathrm{~kg}$ in 2015 and 2016, respectively). In 2015, MH @ 150 ppm was identical with CCC @ 500 ppm in producing fruit weight/plant. In the $2^{\text {nd }}$ year, the second highest fruit weight/plant was obtained from the application of $\mathrm{GA}_{3} @ 30 \mathrm{ppm}(30.1 \mathrm{~kg})$ which was statistically similar to CCC @ 500 ppm $(29.1 \mathrm{~kg})$. The mean values over two years indicated the highest fruit weight/plant $(32.6 \mathrm{~kg})$ was recorded from $\mathrm{MH}$ @ 150 ppm followed by CCC @ 500 ppm $(27.8 \mathrm{~kg})$ and GA 3 @ 30 ppm $(26.0 \mathrm{~kg})$. The lowest fruit weight/plant was found from the control $(11.5 \mathrm{~kg}$ in 2015 and $16.1 \mathrm{~kg}$ in 2016; mean $13.8 \mathrm{~kg}$ ) in both the years.

Fruit yield per hectare followed the same trend of fruit weight/plant. MH 150 ppm gave the highest fruit yield (97.6 t/ha in 2016, $89.6 \mathrm{t} / \mathrm{ha}$ in 2016 and mean $93.6 \mathrm{t} / \mathrm{ha})$. In 2015, CCC @ 500 produced the identical yield (88.5 t/ha) of MH @ 150 ppm. In 2016, application of $\mathrm{GA}_{3} @ 30$ ppm gave the $2^{\text {nd }}$ highest yield 
(74.1 t/ha) which was statistically similar to CCC @ 500 ppm (72.7 t/ha). It was observed from the mean values that the maximum fruit yield $(93.6 \mathrm{t} / \mathrm{ha})$ was recorded from MH @ 150 ppm followed by CCC @ 500 ppm (80.6 t/ha) and $\mathrm{GA}_{3} @ 30 \mathrm{ppm}$ (74.1 t/ha). The control treatment gave the lowest yield (38.5 t/ha and $40.4 \mathrm{t} / \mathrm{ha}$ in 2015 and 2016, respectively; mean 39.4) (Table 4). MH (50-150 $\mathrm{ppm}$ ) produced yields in the range of $70.4-97.6 \mathrm{t} / \mathrm{ha}$ in 2015 and 66.2-89.6 t/ha in 2016. Higher concentration of MH (150 ppm) produced higher yield than $\mathrm{MH} @$ $50 \mathrm{ppm}$ in both the years. On the other hand, $\mathrm{GA}_{3}(10-30 \mathrm{ppm})$ gave the yields ranged from 61.1 -72.8 t/ha in 15 and 52.0-75.3 t/ha in 2016 and GA 3 @ 30 ppm produced the highest yield in both the years. NAA (100-150 ppm) produced fruit yield ranged from 53.5-62.0 t/ha in the first year and from 50.4-56.9 $\mathrm{t} / \mathrm{ha}$ in the $2^{\text {nd }}$ year and NAA @ 150 ppm gave the highest fruit yield in both the years. In mean values over two years, plants of bottle gourd treated with $150 \mathrm{pm} \mathrm{MH,} 500$ ppm CCC and 30 ppm GA $\mathrm{G}_{3}$ gave $54.16 \%, 51.06 \%$ and $46.74 \%$ higher yield, respectively than control. An increase in yield could be attributed to earliness and increased number of female flowers as well as narrowed male:female sex ratio. Arora et al. (1982) reported that MH @ 50 ppm was most effective in producing the maximum fruit weight/plant and ultimately the yield. Foliar spray of MH (50$150 \mathrm{ppm}$ ) increased the yield in most of the cucurbits (Sonkar, 2003; Jatoi et al., 2010). Plants sprayed with MH @ 50 ppm at 2-leaf stage produced the best yield (Baruah and Das, 1997). Saimbhi and Thakur (2006) reported that single spray of CCC @ 500 ppm increased number of fruits per plant and yield in squash melon (Citrullus vulgaris). Sadiq et al. (1990) obtained maximum number of fruits/plant and yield/vine from application of CCC 5@00 in cucumber. Hidayatullah et al. (2012) obtained maximum fruit weight/plant and yield in bottle gourd from the spraying of plants with $\mathrm{GA}_{3} 30 \mathrm{ppm}$. Desai et al. (2011) obtained the maximum yield of bottle gourd from spraying with paclobutrazol @ 25 ppm followed by CCC @ 200 ppm, CCC @ 500 ppm and MH @ 200 ppm.

\section{Partial Economic Analysis}

The present study (Table 5) revealed that the maximum gross return (Tk. $11,70,000.00)$ was found from the plants sprayed with MH @ 150 ppm followed by CCC @ 500 ppm (Tk. 10,07,380.00) and GA 330 ppm (Tk. 9,25,750.00) and the minimum gross return was recorded from control (Tk. 4,93,000.00). Net return showed marked difference among the treatments and followed the same trend of gross return. Net return was the highest (Tk. 9,82,600.00) in MH @ 150 ppm followed by CCC @ 500 ppm (Tk. 8,15,580.00) and GA 3 @ 30 ppm (Tk. $7,35,200.00)$ while the lowest (Tk. 3,06,200.00) in control. The maximum benefit cost ratio (BCR) was obtained from MH @ 150 ppm (5.24) followed by CCC @ 500 ppm (4.25) and $\mathrm{GA}_{3} @ 30$ ppm (3.86); while the minimum from control (1.64). The cost and return analysis revealed that spraying of $\mathrm{MH} @ 150$ ppm was superior to CCC @ 500 and $\mathrm{GA}_{3} @ 30$ ppm in terms of net income and BCR. 
Table 5. Partial cost benefit analysis of summer bottle gourd production by using plant growth regulators

\begin{tabular}{c|c|c|c|c|c|c}
\hline Treatment & $\begin{array}{c}\text { Mean } \\
\text { fruit yield } \\
\text { (t/ha) }\end{array}$ & $\begin{array}{c}\text { Gross } \\
\text { return } \\
\text { ('000 } \\
\text { Tk./ha) }\end{array}$ & $\begin{array}{c}\text { Cost of } \\
\text { treatment } \\
\text { ('000 } \\
\text { Tk./ha) }\end{array}$ & $\begin{array}{c}\text { Cost of } \\
\text { cultivation } \\
\text { ('000 } \\
\text { Tk./ha) }\end{array}$ & $\begin{array}{c}\text { Net return } \\
\text { ('000 } \\
\text { Tk./ha) }\end{array}$ & $\begin{array}{c}\text { Benefit- } \\
\text { cost ratio } \\
\text { (BCR) }\end{array}$ \\
\hline $\mathrm{T}_{0}$ & 39.44 & 493.00 & 0.00 & 186.80 & 306.20 & 1.64 \\
$\mathrm{~T}_{1}$ & 56.54 & 706.75 & 1.25 & 188.05 & 518.70 & 2.76 \\
$\mathrm{~T}_{2}$ & 74.06 & 925.75 & 3.75 & 190.55 & 735.20 & 3.86 \\
$\mathrm{~T}_{3}$ & 51.98 & 649.75 & 0.55 & 187.35 & 462.40 & 2.47 \\
$\mathrm{~T}_{4}$ & 59.44 & 743.00 & 0.83 & 187.63 & 555.38 & 2.96 \\
$\mathrm{~T}_{5}$ & 68.31 & 853.87 & 0.20 & 187.00 & 666.87 & 3.57 \\
$\mathrm{~T}_{6}$ & 93.60 & 1170.00 & 0.60 & 187.40 & 982.60 & 5.24 \\
$\mathrm{~T}_{7}$ & 80.59 & 1007.38 & 5.00 & 191.80 & 815.58 & 4.25 \\
\hline
\end{tabular}

$\mathrm{T}_{0}=$ Control (distilled water), $\mathrm{T}_{1}=\mathrm{GA}_{3} @ 10 \mathrm{ppm}, \mathrm{T}_{2}=\mathrm{GA}_{3} @ 30 \mathrm{ppm}, \mathrm{T}_{3}=\mathrm{NAA} @$ $100 \mathrm{ppm}, \mathrm{T}_{4}=\mathrm{NAA} @ 150 \mathrm{ppm}, \mathrm{T}_{5}=\mathrm{MH} @ 50 \mathrm{ppm}, \mathrm{T}_{6}=\mathrm{MH} @ 150 \mathrm{ppm}, \mathrm{T}_{7}=\mathrm{CCC}$ @ $500 \mathrm{ppm}$.

Basic cost of cultivation: $186800 \mathrm{Tk} . / \mathrm{ha}$.

Cost of PGRs:

1. Gibberellic acid $\left(\mathrm{GA}_{3}\right)$ : Tk. 500.00/g

2. Naphthalelene Acetic Acid (NAA): Tk. 2200.00/100 g

3. Maleic hydrazide : Tk. $1500.00 / 100 \mathrm{~g}$

4. Cycocel (CCC) : Tk. 2000.00/100ml (50\% ai)

$\begin{array}{ll}\text { Treatment } & \text { Dose/ha } \\ \mathrm{GA}_{3} @ 10 \mathrm{ppm}\left(\mathrm{T}_{1}\right) & 2.5 \mathrm{~g} \\ \mathrm{GA}_{3} @ 30 \mathrm{ppm}\left(\mathrm{T}_{2}\right) & 7.5 \mathrm{~g} \\ \text { NAA @ } 100 \mathrm{ppm}\left(\mathrm{T}_{3}\right) & 25.0 \mathrm{~g} \\ \text { NAA } 150 \mathrm{ppm}\left(\mathrm{T}_{4}\right) & 37.5 \mathrm{~g} \\ \text { MH @ 50 ppm }\left(\mathrm{T}_{5}\right) & 13.33 \mathrm{~g} \\ \text { MH @ 150 ppm }\left(\mathrm{T}_{6}\right) & 40.0 \mathrm{~g} \\ \text { CCC @ 500 ppm }\left(\mathrm{T}_{7}\right) & 500 \mathrm{ml}\end{array}$

Market selling price of bottle gourd fruits: Tk. 12.50/kg (Tk 12500.00/ton)

\section{Conclusion}

The experimental result revealed that PGR played a significant role in regulating number of branches/plant, male and female flowering, narrowing sex ratio and ultimately increasing number of fruits and yield. Treatments of MH @ 150 ppm, CCC @ 500 ppm and GA $@ 30$ ppm were superior to the rest of the treatments for the earliness of female flower appearance, narrowing down sex-ratio and 
finally increasing yield. These three treatments also registered higher gross return, net return and BCR. Therefore, it can be concluded that spraying $\mathrm{MH}$ @ 150 ppm or CCC @ 500 ppm or $\mathrm{GA}_{3} @ 30$ ppm to the seedlings of bottle gourd at two-leaf stage and $2^{\text {nd }}$ spraying after four days of $1^{\text {st }}$ spray should be done in summer to get higher yield with higher return.

\section{References}

Ansari, A. M. and B. M. Choudhury. 2014. Effects of boron and plant growth regulators on vegetative, physiological and fruit characters of bottle gourd (Lagenaria siceraria (Molina) Standle). Progressive Res. 9 (conf. suppl.): 974-978.

Arora, S. K., M. L. Pandita and A. S. Sidhu. 1982. Effect of maleic hydrazide on vegetative growth, flowering and fruiting of bottle gourd. Scientia Horticulturae. 17(3): 211-215.

Baruah, G. K. S and R. K. Das. 1997. Effect of plant growth regulators on growth, flowering and yield of bottle gourd at different sowing dates. Ann. of Agril. Res. 18(3): 371-374.

Browning, G., Z. Singh, A. Kuden and P. Blake. 1992. Effect of paclobutrazol on endogenous indol-3-acetic acid in shoot apices of pear cv. Doyenne do Comice. Hort. Sci. 67: 129-135.

Choudhury, B. 1966. Modification of sex by plant regulators spraying on cucurbits under high temperature and long day conditions. Proc. $17^{\text {th }}$ Int. Hort. Cong. Md. L. Abstr. 191.

Desai. K. D., S. N. Saravaiya, , B. N. Patel and N. B. Patel. 2011. Response of growth retardants on sex expression and fruit yield of bottle gourd [Lagenaria siceraria (Mol.) Standl.] cv. Pusa Naveen under South Gujrat conditions. The Asian J. Hort. 6(1): $22-25$

Gaurav, S. S., S. P. S. Sirohi, R. Yadov and P. Sirohi. 2008. Effect of plant growth regulators on growth, yield and sex expression on bottle gourd (Lagenaria siceraria). J. Plant Archives. 8 (2): 1029-1031.

Heslop-Harrison, J. 1957. The experimental modification of sex expression in flowering plants. Bio. Rev. 32: 38-90.

Hidayatullah, T., M. Mahmood, M. Farooq, M. A. Khokhar and S. I. Hossain. 2012. Plant growth regulators affecting sex expression of bottle gourd ( Lagenaria siceraria Molina) plants. Pakistan J. Agric. Res. 25 (1): 50-54.

Huyskens, S., S. Mendlinger, A. Benzioni and M. Ventura. 1992. Optimization of agrotechniques for cultivating Momordica charantia (Karela). J. Hort. Sci. 67: 259264.

Ingle, V. G., B. J. Jadhao and P. S. Joshi. 2000. Effect of plant growth regulators on growth, sex ratio and yield of bottle gourd. J. Soils Crops. 10 (1): 101-104.

Jatoi, S. A., A. Kikuchi, D. Ahmad and K. N. Watanabe. 2010. Characterization of the genetic structure of mango ginger (Curcuma amada Roxb.) from Myanmar in farm and gene bank collection by the natural and functional genomic markers. Electronic 
J. Biotechnol. 13:6. [Available from http://www.ejbiotechnology.info accessed on 12.11.2017].

Kooner, K. S., S. Jaskaran, and M. S. Saimbhi. 2000. Effect of plant growth substances on growth, sex expression and fruit yield in bottle gourd cv. Punjab Komal. Haryana J. Hort. Sci. 29: (3/4):268-269.

Krishnamurthy, H. N. 2011. Plant Growth Substances. Tata McGraw-Hill Pub. Com. Ltd. New Delhi.

Kumar, S., S. K. Dixit and H. R. Mishra. 2000. Effect of plant growth regulatiors on yield and yield contributing characters of bottle gourd (Lagenaria siceraria Molina). Advances in Plant Sci. 19 (2): 419-421.

Leghari, M. H., A. A. Mugheri, S. A. Sheikh, N. A. Wahocho. 2014. Response of nitrogen levels on the growth and yield of bottle gourd varieties. Int. J. of Agron. and Agril. Res. (IJAAR). 5 (6): 86-92.

Pandey, R. P. and K. Singh. 1976. Effect of plant growth regulators on sex expression, fruit set and yield of sponge gourd (Luffa cylindrica Poem.). Hort. Abstract. 499(11): 733.

Pandya, M. B. and C. K. Dixit. 1997. Effect of plant growth regulators and chemicals on the growth, sex behavior and yield of bottle gourd [[Lagenaria siceraria (Mollina) Stand]. Cv. Pusa Summer Prolific Long. J. Applied Hort. 3(1\&2): 105-111.

Patel, A. K. 1992. Assessment of the effectiveness of MH and NAA on growth, sex expression and yield of bottle gourd [Lagenaria siceraria (Mollina) Stand) cv. Pattiwali. M.Sc (Ag.) Thesis, GAU, Sardarkrushinagar, Gujrat, India.

Quamruzzaman, A. K. M., L. Akter, M. H. Rahman and M. T. Rahman. 2015. Preliminary yield trial of bottle gourd lines for summer season. Research Report on Horticultural Crops 2014-2015. Olericulture Division, Horticulture Research centre, Bangladesh Agricultural Research Institute, Gazipur. pp. 90-92.

Rahman, M. A. and M. R. Karim. 1997. Effect of foliar treatment of NAA, TIBA and $\mathrm{GA}_{3}$ on vegetative growth, NPK concentration, sex expression and yield of bottle gourd (Lagenaria siceraria). Chittagong University Studies. Science. 21(1): 9-13.

Sadiq, W. M., H. Inatullah and A. Wahdud. 1990. Effect of different doses of cycocel (CCC) on growth and yield of cucumber. Sarhad J. Agric. 6(1): 61-65.

Saimbhi, M. S. and M. R. Thakur. 2006. Growth, sex expression and yield of squash melon (Citrullus vulgaris var. fistulosus) as influenced by 2 (Chloroethyl) trimethylammonium chloride. Physiologia Plantarum. 28(3): 383-387.

Sharma, N. K., S. K. Arora and B. S. Dhankhar. 1988. Effect of plant growth substances on growth, flowering, sex expression and fruit yield in bottle gourd [Lagenaria siceraria (Mollina) Stand]. Haryana Agric. Univ. J. Res. 18(4): 291-297.

Singh, R. K. and B. Choudhury. 1988. Differential response of chemicals on sex modifications of three genera of cucurbits. Indian J. Hort. 45(1-2): 88-99.

Sonkar, S. K. 2003. Effect of plant growth regulators on sex expression and yield of pumkin (Cucurbita moschata Dutch. Ex. Poir). M.Sc. Thesis, VBS Poorvanchal University, Jaunpur, India. 